\title{
Local Application of Corticosteroids Combined with Surgery for the Treatment of Chronic Subdural Hematoma
}

\author{
Kronik Subdural Hematom Tedavisinde Cerrabi ile Kombine Olarak \\ Lokal Kortikosteroid Uygulamast
}

Xiao-Ping XU, Cong LIU, Jian LIU, Yuan-Guang PANG, Xu-Dong LUO, Jun FU, Liang ZHOU, Ying-Zhong FAN

The First People's Hospital of Neijiang, Department of Neurosurgery, Neijiang, Sichuan, China

Corresponding Author: Cong LIU / E-mail: njyyliucong@163.com

\begin{abstract}
AIM: Combination treatment consisting of surgery and pre-or post-operative corticosteroids for chronic subdural hematoma (CSH) tend to have better outcomes than surgery only. However, there are many complications after long-term use of corticosteroids. In this study, we evaluated the clinical outcomes of local application of corticosteroids combined with surgery for CSH.

MATERIAL and METHODS: We retrospectively analysed the data of the patients undergoing surgery and local application of Methylprednisolone Sodium Succinate for Injection (MPSS) into the hematoma cavity. Neurological status was assessed by Markwalder's Grading Scale (MGS). Recurrence was defined as deteriorating neurological status with radiological evidence of reaccumulation.

RESULTS: A total of 26 patients were enrolled in this study. During the follow-up period, all patients made excellent neurological recovery. 24 (92.3\%) patients' MGS was grade 0 at 12 months after the surgery. There was no mortality or recurrence. 5 patients (19.2\%) suffered postoperative complications, of which 2 developed some subdural air collection, 2 had a partial seizure attack and 1 developed an acute epidural hemorrhage.
\end{abstract}

CONCLUSION: The results suggest that local application of MPSS combined with surgery is a safe and effective method in the management of $\mathrm{CSH}$. It may reduce hematoma recurrence.

KEYWORDS: Chronic subdural hematoma, Surgery, Corticosteroids, Local application

\section{öz}

AMAÇ: Kronik subdural hematom (KSH) için cerrahi ve preoperatif veya postoperatif kortikosteroidlerden oluşan kombinasyon tedavisinin sonuçları tek başına cerrahiden daha iyi olma eğilimindedir. Ancak kortikosteroidlerin uzun dönem kullanımından sonra birçok komplikasyon vardır. Bu çalışmada KSH için cerrahi ile kombine olarak lokal kortikosteroid uygulamasının klinik sonuçlarını değerlendirdik.

YÖNTEM ve GEREÇLER: Hematom boşluğuna Metilprednizolon Sodyum Süksinat (MPSS)ın enjeksiyon ile lokal uygulaması ve cerrahi yapılan hastaların verilerini retrospektif olarak analiz ettik. Nörolojik değerlendirme Markwalder Derecelendirme Ölçeği (MGS) ile yapıldı. Nüks, radyolojik tekrar birikim bulgusuyla birlikte bozulan nörolojik durum olarak tanımlandı.

BULGULAR: Çalışmaya toplam 26 hasta dahil edildi. Takip döneminde tüm hastalar nörolojik açıdan mükemmel iyileşme gösterdi. Yirmi dört $(\% 92,3)$ hastada cerrahiden 12 ay sonra MGS 0 olarakbulundu. Mortalite veya nüks yoktu. Beş hastada $(\% 19,2)$ postoperatif komplikasyonlar görüldü ve bunların 2'sinde bir miktar subdural hava toplanması, 2'sinde kısmi havale atağı ve 1'inde akut epidural kanama gelişti.

SONUÇ: Sonuçlarımız, cerrahiyle kombine olarak yerel MPSS uygulamasının kronik subdural hematom yönetiminde güvenli ve etkin bir yöntem olduğuna işaret etmektedir. Hematom nüksünü de azaltabilir.

ANAHTAR SÖZCÜKLER: Kronik subdural hematom, Cerrahi, Kortikosteroidler, Lokal uygulama

\section{INTRODUCTION}

Chronic subdural hematoma (CSH) has been treated with various procedures. In most cases surgical treatment is the first choice and its clinical outcome is good, but have experienced a considerable number of cases in which surgical complications and recurrence rates are high. Many researchers also reported the efficacy of general use of dexamethasone (oral or intravenous) in the treatment of $\mathrm{CSH}$, and obtained favourable results $(4,5,24)$. Combination treatment consisting of surgery and pre-operative or post-operative corticosteroids tends to have better outcomes $(2,3,5,6,24)$, but there can be complications such as infections, gastrointestinal bleeding, and hyperglycemia after general administration of long-term corticosteroids. Endo et al. reported successful treatment of a case of infantile subdural fluid collection by injection of $8 \mathrm{mg}$ methylprednisolone acetate (MPA) into the subdural cavity (7). However, to our knowledge, there is no report of local 
use of corticosteroids in the management of $\mathrm{CSH}$. Here we report the clinical results of 26 patients treated by local use of corticosteroids into the hematoma cavity combined with surgery.

\section{MATERIAL and METHODS}

We retrospectively analysed the data of 26 patients with $\mathrm{CSH}$ who were admitted to the Department of Neurosurgery, First People's Hospital of Neijiang, China, where they underwent surgery and received a local application of Methylprednisolone Sodium Succinate for Injection (MPSS) into the hematoma cavity between January 2003 and March 2007. This study was conducted in accordance with the declaration of Helsinki and under approval from the Ethics Committee of the First People's Hospital of Neijiang, China. Written informed consent was obtained from all participants. All cases of $\mathrm{CSH}$ were diagnosed by computed tomographic scanning (CT) and/or magnetic resonance imaging (MRI).

\section{Surgical Procedure}

The patients were kept in a lateral position, except 3 patients with bilateral $\mathrm{CSH}$ needing repositioning during operation. We treated bilateral hematomas as one case, and both sides received the same treatment. Under local anesthesia, while general anesthesia was performed when anesthetics judged it to be too risky for surgery. A single burr hole was drilled over the maximum thickness of the hematoma, and the hematoma cavity was intensively irrigated with physiological saline solution using a small catheter mounted on a syringe. The catheter was manipulated into the corners of the cavity to wash out the clots and insure free communication of all parts of the cavity. When the irrigation fluid was clear, the hematoma cavity was filled with physiological saline solution and a post-operative closed drainage system with a ventricular catheter mounted on a T-tubes was inserted in the frontal subdural space. 48-72 hours later, when drainage had ceased, $10 \mathrm{mg}$ of Methylprednisolone Sodium Succinate for Injection (MPSS) was dissolved in $5 \mathrm{ml}$ saline and administrated into the hematoma cavity through the T-tubes. Then the drainage system was removed.

\section{Follow-up Study}

CT scan and/or MRI was performed on admission, at the time when the drainage system was removed, and at 12 months after the operation if patients' symptoms did not recur. Neurological status was assessed by Markwalder's Grading Scale (MGS), which is the most commonly used neurological grading system for $\mathrm{CSH}$, on admission, 1 day after the operation, at discharge and 12 months after the operation (15). Recurrence was defined as deteriorating neurological status with radiological evidence of reaccumulation.

\section{RESULTS}

A total of 26 consecutive patients with a diagnosis of CSH were included. The mean duration of hospitalization was 6.7 days. Mean age was 65.8 years, ranging from 10 to 85 years and there were 23 men and 3 women. $84.6 \%$ of the patients were treated under local anesthesia, and 4 patients under general anesthesia. A single burr hole was drilled in 23 patients (left: right=17: 6), and bilateral drilling was performed in 3 patients. $76.9 \%$ of the patients revealed a previous history of mild or moderate head trauma several weeks/months before admission. Other risk factors included hypertension (19.2\%), anticoagulant medication intake (30.8\%), cardiomyopathy (11.5\%), and type-2 diabetes (3.8\%).

Headache and instability were the most common symptoms (69.2\%), followed by mental confusion, drowsiness and impaired cognition. The indication for surgery was based mainly on progressive neurological deficits and midline shift of some degree on CT findings. On admission, 23 patients harboured a unilateral $\mathrm{CSH}$ and 3 were bilateral. All the unilateral $\mathrm{CSH}$ patients were found to have midline shift of some degree.

There was no mortality and we observed good recovery of neurological status at discharge for most patients (Table I). Post-operative complications were also recorded with 2 patients developing some subdural air collection, 2 with a partial seizure attack and 1 patient suffering from an acute epidural hemorrhage near the drilling site with no need for a second surgical intervention. 12 months after the operation, $92.3 \%$ of the patients' Markwalder score was grade 0 . During the 12-month follow-up, no patient had symptoms or radiological evidence of recurrence.

\section{DISCUSSION}

Up to now, there have been no studies to determine which surgical approach is most appropriate for the treatment of $\mathrm{CSH}$. As has been presented, we combined surgery and local application of MPSS into the hematoma cavity to treat $\mathrm{CSH}$, and excellent neurological recovery was found. At 12 months after the operation, 24 patients' Markwalder score was grade 0 . Surprisingly, no recurrence and negative side effects of local application of MPSS were observed, which suggests that local application of MPSS combined with surgery for the treatment of $\mathrm{CSH}$ is effective and safe.

To our knowledge, this is the first time of local use MPSS in the management of CSH. Shunro Endo et al. (7) reported successful treatment of a case of infantile subdural fluid collection by administration of $8 \mathrm{mg}$ methylprednisolone acetate (MPA) into the subdural cavity when continuous subdural drainage and subdural peritoneal shunt failed. A questionnaire survey showed that $42 \%$ responded that they never prescribed corticosteroids and 55\% stated that they prescribed them only to those managed conservatively (21). Previous studies showed that general application of corticosteroids (oral or intravenous or intramuscular) obtained favourable results $(5,24)$. Delgado-López et al. large retrospective series (101 cases) suggested that dexamethasone was a feasible and safe alternative in the management of $\mathrm{CSH}$ (5), but it could only be applied to a small number of selective patients. Combination treatment consisting of surgery and corticosteroids either given before or after surgery seems to have better results 
Table I: Clinical Outcome Measured by the MGS (No. of patients)

\begin{tabular}{l|c|c|c|c|c} 
& \multicolumn{5}{|c|}{ MGS } \\
\cline { 2 - 6 } & 0 & 1 & 2 & 3 & 11 \\
On admission & - & 2 & 13 & - & - \\
1 day po. & 3 & 18 & 5 & - & - \\
At discharge & 23 & 3 & - & - \\
12 month po. & 26 & - & - & -
\end{tabular}

po.= post-operative, Markwalder Grading Scale: Grade 0: Neurologically normal; Grade 1: Patient alert and oriented; mild symptoms, such as headache; absent or mild symptoms or neurological deficit, such as reflex asymmetry; Grade 2: Drowsy or disorientated, or variable neurological deficit such as hemiparesis; Grade 3: Stuporous, but responding appropriately to noxious stimuli, several focal signs such as hemiplegia; Grade 4: Comatose with absent motor responses to painful stimuli, decerebrate or decorticate posturing.

$(2,3,5,24)$, but negative side effects of general application of the corticosteroids such as hyperglycemia, nosocomial infections, gastrointestinal bleeding etc. were observed when used for longer periods, the frequency and severity of adverse effects increases dramatically. Local use of corticosteroids can minimize the side effects, and excellent recovery and no recurrence were observed in our report.

Contemporary options for treating $\mathrm{CSH}$ range from simple twist drill craniostomy without drainage to large craniotomies with marsupialisation of hematoma membranes $(8,18)$. Burr hole craniotomy $(\mathrm{BHC})$ followed by irrigation of the subdural space, with or without drainage, is a widespread treatment for $\mathrm{CSH}(16,19,27)$. Recurrence rates after the initial drainage procedure range from roughly $5 \%$ to $30 \%$, and is a focus of research $(19,27)$. Thomas Santarius and his colleagues' randomised controlled trial study showed that patients with $\mathrm{CSH}$ treated with burr-hole evacuation and post-operative drainage had a recurrence rate roughly half that of those without drainage (20).

To prevent recurrence of hematoma, Aoki et al. (1) filled the hematoma cavity with oxygen via percutaneous subdural tapping, and found that the recurrence fell to $5 \%$. They concluded that this method eliminated the risk of tension pneumocephalus so long as the inner hematoma membrane was not injured. In comparison with oxygen, Kitakami A et al. (13) used $\mathrm{CO}_{2}$ gas to fill the hematoma cavity. $\mathrm{CO}_{2}$ is more rapidly absorbed and facilitates the disappearance of the hematoma cavity and reexpansion of the brain. They found rapid disappearance of the hematoma cavity and almost complete disappearance of the gas within 24 hours of injection of $\mathrm{CO} 2$.

Although corticosteroids have been proven to be clinically effective in the treatment of $\mathrm{CSH}$, the mechanism is still unclear. CSH is currently considered to be a circumscribed chronic self-perpetuating inflammatory disorder that involves the dura mater (23). When CSF or extravasated blood gathers into the restricted area of the dural border cell layer $(10,14,17)$, it evokes a local aseptic inflammatory $(9,26)$ and inflammation-induced angiogenic reactions (11, $12,22,25)$. The result is that glucocorticoids may specifically impede the formation of neomembranes and neo-capillaries by their powerful inhibition of inflammatory mediators (23). More basic research is needed to clarify the true role of the corticosteroids in the treatment of chronic subdural hematoma.

\section{CONCLUSION}

Our data suggests that local application of MPSS into the hematoma cavity combined with surgery is a safe and effective method in the management of $\mathrm{CSH}$. It may reduce hematoma recurrence. Nevertheless, given the small number of patients and lack of a control group, future carefully designed, prospective, randomized trials are necessary to definitively address these management issues.

\section{ACKNOWLEDGMENTS}

The authors would like to thank Qian Wu for his help in editing the article.

\section{REFERENCES}

1. Aoki N: A new therapeutic method for chronic subdural hematoma in adults: Replacement of the hematoma with oxygen via percutaneous subdural tapping. Surg Neurol 38:253-256, 1992

2. Bender MB, Christoff N: Nonsurgical treatment of subdural hematomas. Arch Neurol 31:73-79,1974

3. Berghauser Pont LM, Dirven CM, Dippel DW, Verweij BH, Dammers R: The role of corticosteroids in the management of chronic subdural hematoma: A systematic review. Eur J Neurol 19:1397-1403,2012

4. Decaux O, Cador B, Dufour T, Jego P, Cazalets C, Laurat E, Grosbois B: Nonsurgical treatment of chronic subdural hematoma with steroids: Two case reports. Rev Med Interne 23:788-791,2002

5. Delgado-Lopez PD, Martin-Velasco V, Castilla-Diez JM, Rodriguez-Salazar A, Galacho-Harriero AM, FernandezArconada O: Dexamethasone treatment in chronic subdural haematoma. Neurocirugia (Astur) 20:346-359,2009

6. Dran G, Berthier F, Fontaine D, Rasenrarijao D, Paquis P: Effectiveness of adjuvant corticosteroid therapy for chronic subdural hematoma: A retrospective study of 198 cases. Neurochirurgie 53:477-482,2007 
7. Endo S, Hirashima $Y$, Takaba M, Takaku A: Administration of methylprednisolone acetate into the subdural cavity in an infant with subdural fluid collection. PAF is a good indicator of the efficacy of the treatment. Childs Nerv Syst 14: 354-356,1998

8. Ernestus Rl, Beldzinski P, Lanfermann H, Klug N: Chronic subdural hematoma: Surgical treatment and outcome in 104 patients. Surg Neurol 48:220-225,1997

9. Frati A, Salvati M, Mainiero F, Ippoliti F, Rocchi G, Raco A, Caroli E, Cantore G, Delfini R: Inflammation markers and risk factors for recurrence in 35 patients with a posttraumatic chronic subdural hematoma: A prospective study. J Neurosurg 100:24-32,2004

10. Haines DE, Harkey HL, al-Mefty O: The "subdural" space: A new look at an outdated concept. Neurosurgery 32:111-120,1993

11. Hohenstein A, Erber R, Schilling L, Weigel R: Increased mRNA expression of VEGF within the hematoma and imbalance of angiopoietin-1 and -2 mRNA within the neomembranes of chronic subdural hematoma. J Neurotrauma 22:518-528,2005

12. Katano H, Kamiya K, Mase M, Tanikawa M, Yamada K: Tissue plasminogen activator in chronic subdural hematomas as a predictor of recurrence. J Neurosurg 104:79-84,2006

13. Kitakami A, Ogawa A, Hakozaki S, Kidoguchi J, Obonai C, Kubo N: Carbon dioxide gas replacement of chronic subdural hematoma using single burr-hole irrigation. Surg Neurol 43:574-577; discussion 577-578, 1995

14. Mack J, Squier W, Eastman JT: Anatomy and development of the meninges: Implications for subdural collections and CSF circulation. Pediatr Radiol 39:200-210,2009

15. Markwalder TM, Steinsiepe KF, Rohner M, Reichenbach W, Markwalder $\mathrm{H}$ : The course of chronic subdural hematomas after burr-hole craniostomy and closed-system drainage. J Neurosurg 55:390-396,1981

16. Muzii VF, Bistazzoni S, Zalaffi A, Carangelo B, Mariottini A, Palma L: Chronic subdural hematoma: Comparison of two surgical techniques. Preliminary results of a prospective randomized study. J Neurosurg Sci 49:41-46; discussion 4647,2005

17. Reina MA, De Leon Casasola O, Lopez A, De Andres JA, Mora $M$, Fernandez A: The origin of the spinal subdural space: Ultrastructure findings. Anesth Analg 94:991-995,2002
18. Reinges MH, Hasselberg I, Rohde V, Kuker W, Gilsbach JM: Prospective analysis of bedside percutaneous subdural tapping for the treatment of chronic subdural haematoma in adults. J Neurol Neurosurg Psychiatry 69:40-47,2000

19. Santarius T, Hutchinson PJ: Chronic subdural haematoma: Time to rationalize treatment? $\mathrm{Br} \mathrm{J}$ Neurosurg 18:328332,2004

20. Santarius T, Kirkpatrick PJ, Ganesan D, Chia HL, Jalloh I, Smielewski P, Richards HK, Marcus H, Parker RA, Price SJ, Kirollos RW, Pickard JD, Hutchinson PJ: Use of drains versus no drains after burr-hole evacuation of chronic subdural haematoma: A randomised controlled trial. Lancet 374: 1067-1073,2009

21. Santarius T, Lawton R, Kirkpatrick PJ, Hutchinson PJ: The management of primary chronic subdural haematoma: $A$ questionnaire survey of practice in the United Kingdom and the Republic of Ireland. Br J Neurosurg 22:529-534,2008

22. Shono T, Inamura T, Morioka T, Matsumoto K, Suzuki SO, Ikezaki K, Iwaki T, Fukui M: Vascular endothelial growth factor in chronic subdural haematomas. J Clin Neurosci 8: 411-415,2001

23. Stanisic M, Aasen AO, Pripp AH, Lindegaard KF, RammPettersen J, Lyngstadaas SP, Ivanovic J, Konglund A, Ilstad E, Sandell T, Ellingsen O, Saehle T: Local and systemic proinflammatory and anti-inflammatory cytokine patterns in patients with chronic subdural hematoma: A prospective study. Inflamm Res 61:845-852,2012

24. Sun TF, Boet R, Poon WS: Non-surgical primary treatment of chronic subdural haematoma: Preliminary results of using dexamethasone. Br J Neurosurg 19:327-333,2005

25. Vaquero J, Zurita M, Cincu R: Vascular endothelial growthpermeability factor in granulation tissue of chronic subdural haematomas. Acta Neurochir (Wien) 144:343-346,2002

26. Wada T, Kuroda K, Yoshida Y, Ogasawara K, Ogawa A, Endo S: Local elevation of the anti-inflammatory interleukin-10 in the pathogenesis of chronic subdural hematoma. Neurosurg Rev 29:242-245,2006

27. Weigel R, Schmiedek P, Krauss JK: Outcome of contemporary surgery for chronic subdural haematoma: Evidence based review. J Neurol Neurosurg Psychiatry 74:937-943,2003 